Journal of Nepal Geological Society, Vol. 7, 1991, 9-20

\title{
BIOSTRATIGRAPHIC REPORTS - SPURIOUS AND DUBIOUS - FROM MEPAL
}

John A. Talent ${ }^{1}$, Gopal M.S. Dongol and Vinod Singh Chhetri ${ }^{3}$.

1 Earth Sciences, Macquarie University, NSW 2109, Australia

2 Department of Mines and Geology, HMG, Kathmandu, Nepal

3 P.O. Box 4141, Kathmandu, Nepal.

\section{ABSTRACT}

With one exception, a fauna known to be collected by someone else, illustrated reports of fossils by V.J. Gupta from the Palaeozoic to Pleistocene of Nepal are stratigraphically bizarre, can not be replicated, and should therefore be ignored in stratigraphic syntheses. All Gupta identifications lacking illustrations ara also best disregarded.

\section{INTRODUCTION}

Much data has been produced arguing that V.J. Gupta's voluminous output (at last count, 456 publications including 5 books) should be ignored in syntheses of the geology of the Himalayan region from Pakistan to Bhutan (Talent et al., 1988,1989,1990; Talent 1989 a, 1989 b, 1989 c, 1990 a, 1990 b, 1990 c, in press; Lewin, 1989; Ahluwalia et al., 1989; Sahni, 1989; Radhakrishna, 1989,1990; Bassi, 1989; Anonymous, 1990; Brock et al., 1990; Webster, 1990; Wyatt, 1990). Gupta has attempted to reply but has consistently evaded the charges (Gupta, 1989, 1990 a, 1990 b; cf. Bhatia et al., 1990). He has had strong supporters (R.C. Kanwar, A.K. Prasad, Naresh Kochhar) in his own institution who have written. letters to newspapers, especially the Tribune, on his behalf, but none, apart from his principal co-author J.B. Waterhouse $(1989,1990)$, has come out with suppo-ting statements in scientific journals. Waterhouse's attempted defence has been addressed elsewhere (Talent, 1990 a, 1990 b). Because Gupta's reports involve a number of localities in Nepal, we have deemed it useful to present the basic bibliography on the Gupta debate as well as indicate incongruous aspects of the various discoveries he ciaims to have made in Nepal.

One specially bizarre aspect is that Gupta (1989) claims his Nepalese fossil discoveries were made during field work with one 
of us (V.S.C.). Gupta's travels in Nepal in association with Chhetri took place in June 1974, and were limited to examination of the lower half of the Phulchauki section (cf. Talent et al., 1988, Fig. 4), supplemented by a brief look at the clastic sequence (Chandragiri Formation) exposed in the Santhneshwar Range about $3.5, \mathrm{~km}$ northwest of Godavari. These peregrinations did not include examination of the critical upper half of the Phulchauki section from which Gupta was to report Late Devonian conodonts. Nor did they include examination of any section in the Chandragiri Range or in the Chapagaon/Nakhu Khola areas from which he subsequently made reports of fossils. A few lithological samples were collected by Gupta during this visit, but no macro-fossils of any kind. No manuscript of the Gupta \& Chhetri (1977) paper was sent to Chhetri for approval. He was therefore surprised to find reports of fossils from the Phulchauki area. As he wished to replicate Gupta's discoveries, especially of the conodonts (Gupta, 1975 a ) he wrote to Gupta seeking additional data, duplicate specimens for museum displays; and information on techniques. His requests were ignored.

\section{COMMENTARY ON GUPTA'S NEPALESE REPORTS}

\section{The Cystoids From the Chandragiri Pass}

Gupta (1980) describes his "fresh collections" of cystoids to have come from "limestone exposed at the milestone 500 metres from the Chandragiri pass on the Chandragiri-Kathmandu road". Superficially, this may seem to have a measure of accuracy about it, but there are 6 curious features of this report and its predecessor (Gupta \& Termier, 1978):

i. Omission of reference to the paper, published two years previously (Gupta \& Termier, 1978) in which the cystoid remains were described by Mme Genevieve Termier. In the 1980 paper she is merely thanked for comments.

ii. Apparent confusion between the Thankot-Chitlang-Chisapani mule track across the Chandragiri Range and the main road from Kathmandu to the Nepal-India border at Birganj and Raxaul. The former is without kilometre or mile posts. The latter has kilometre posts and leaves the Kathmandu Valley through the Naghdunga Pass, sometimes incorrectly referred to as the Chandragiri Pass. There are no limestones in the vicinity of the kilometre posts on either side of the latter pass, only siltstones or phyllitic siltstones. 
Journal of Nepal Geological Society, Vol. 7, 1991, 9-20

iii. Lithologies of the 2000-2500 $\mathrm{m}$ Chandragiri Limestone (Stocklin \& Bhattarai, 1977), when not modified by recrystallization, suggest a rapidly accumulated platform carbonate sequence. It is curious therefore that cystoids, said to have come from horizons only $20 \mathrm{~m}$. apart, should suggest ages so vastly different: Middle Cambrian and Middle Ordovician.

iv. The cystoids are distinctly central European (Bohemian) as regards biogeographic affinities.

v. The greasy nature of the specimens, noted by Mme Termier (in Gupta \& Termier, 1978). She (pers. comm.) now considers this greasiness as probably indicative of derivation from teaching collections handled by generations of students.

vi. Despite Gupta's (1989) claim that his collections in Nepal were made during joint field work with Vinod Singh Chhetri, the latter (see above) testifies that no Chandragiri Range sections were examined with Gupta, nor for that matter were any macro-fossils collected while they were together.

In view of the above, we regard Gupta's cystoid reports as almost certainly spurious and recommend they be ignored in regional syntheses until such time as similarly greasy specimens are found, by independent investigators, $500 \mathrm{~m}$. or so from any pass - no matter which - leading out of the Kathmandu Valley.

\section{The Shelly Faunas From Khotkhu Khola and Godavari Phulchauki}

An uncritical listing of macro-fossils, derived from previous works (mainly unpublished), was presented by Gupta (in Gupta \& Chhetri, 1977) for "the Phulchauki-Chandragiri area". Lists of additional fossils "in a poor state of preservation" were presented by Gupta for the Godavari-Phulchauki area and from "near the barrage over the Kokdu Nallaha $(=$ Khotkhu or Kodku Khola) about $3.5 \mathrm{~km}$ northwest of Godavari. These lists are curious for the following reasons:

i. The taxonomy is archaic, 80 - 100 years out of date.

ii. Gupta was obviously unaware of the existence of Bordet, Calvet and Pillet's (1960) monograph, the one major item of descriptive taxonomy carried out on the ordovician-Silurian trilobites and brachiopods from Phulchauki. 
iii. We have been able to duplicate Bordet et. al. faunas, but not the taxa listed by Gupta from the Godavari Phulchauki sequence. Gupta asserts this fauna to "closely resemble" faunas he has reported from "Naubug Beds" of Kashmir. The latter "fauna" has been categorized taxonomically as junk (evaluations, in Talent et. al., 1988, pp. 33 - 34). To closely resemble such a collage would be indeed remarkable!

iv. We have examined the superbly outcropping sequence of quartzites and subordinate dark blue-qrey (not greyish white) calcareous quarzites and carbonates in the gorge immediately downstream from the barrage on the Kodku Khola and have found neither brachiopods nor crinoids. We did note, outcropping on the left bank, a bed of impure limestone with an abundance of small calcite-filled tension gashes $1-2 \mathrm{~cm}$ in length, arranged en echelon. At first sight these might be mistaken for cross-sections of brachiopods, but they are all inclined at an angle to the * bedding. Curiously, one of us (V.S.C.) who took Gupta to the area recalls that Gupta did not descend into the gorge. Their visit was skimpy, involving no nore than a brief wander around the hilltop overlooking the gorge, just southwest of the village of Bandegaon.

v. No macrofossils were collected by Gupta either in the vicinity of Kodku Khola barrage or in the Godavari Phulchauki area during the time he was with Chhetri.

In view of the above, we suggest that no credibility should be accorded Gupta's lists of shelly fossils from central Nepal.

\section{Melocrinites From Phulchauki.}

The report (Gupta \& Webster, 1976) of a partial crown of the Early or Middle Devonian crinoid Melocrinites $\mathrm{sp}$. from $15.5 \mathrm{Km}$ from Godavari School" on the Godavari-Phulchauki road is anomalous. It has already been pointed out (Talent et al ., 1988, p. 18) that the locality in question is "without fossils, macro or micro", is approximately $140 \mathrm{~m}$ stratigraphically beneath a horizon that has produced Early Llandovery (earliest Silurian) conodonts, and also stratigraphically beneath the Llandovery Wenlock trilobite fauna described by Pillet (in Bordet et al., 1960). We therefore believe the report should be disregarded. 
Journal of Nepal Geological Society, Vol. 7, 1991, 9-20

\section{The Late Devonian Conodont Fauna From Phulchauki}

As already pointed out (Talent et al.,1988,p.17; Talent 1989, 1990 c, p. 47) there are a number of curious things connected with this report. These and additional points are:

i. The fauna is highly specific to a thin limestone unit the early Frasnian (earliest Late Devonian) North Evans Limestone, outcropping in Amsdell Creek, New York state- a remarkable association of conodonts (including 2 endemics) winnowed from 3 possibly 4 horizons (Talent et al., 1988, p. 17).

ii. Extensive sampling of carbonates from top to bottom of the sequence exposed on the Godavari-Phulchauki road (Talent ot al., 1988) failed to find conodonts younger than earliest Silurian, admittedly stratigraphically beneath the horizon from which Gupta claims to have made his discovery. The precise spot was not sampled in 1975 but was reinvestigated on 26 September 1990. It consists of coarsely recrystallized, unfossiliferous limestone: a context not in the least prospective for conodonts.

iii. Gupta has used (recycled) 3 specimens supposedly from Phulchauki - precisely the same specimens - as part of his 'documentation' of an early Late Devonian fauna supposedly from Kishtwar in northwest India (Gupta, 1975 b; Talent et al., 1988, p. 17; Talent 1989 a); the bedrock at Kishtwar is gneisses for many kilometres in all directions. The Amsdell Creek fauna, incidentally, has been reported by Gupta from several other localities in the Himalaya of India but without documentation.

iv. Anthony Wyatt (1990) has opined that the Amsdell Creek materials used for Gupta's reports may have come from collections at the University of Aberystwyth - where Gupta had been, with unrestricted access to the collections (to which he had helped himself - see Talent et al., 1989,1990) just prior to his first conodont report.

v. In June, 1974, Gupta and one of us (V.S.C.) climbed the foot-track from Godavari to the old iron mine, close to the area labelled 'Camp Site' by Talent et al.' (1988, Fig. 4), rootled around the mine and then returned to Godavari. The highest point reached by Gupta was thus topographically 1100 $\mathrm{m}$. or so below and a good $6 \mathrm{~km}$ by road short of the spot he 
would subsequently designate as the site of his Late Devonian conodont 'discovery'.

vi Though Gupta's Phulchauki map (Gupta, 1975 a; Gupta \& Chhetri, (1977) bears the inscription 'Gupta 1974', the map has in fact been plagiarized from an unpublished Geological Survey of India report loaned to Gupta by Chhetri.

vii. Perhaps even more curious is that Gupta was at Marburg University in 1973 where he had gone to learn more about conodonts from a world-authority on the group, Prof. Dr. Willi Ziegler. As the conodonts Gupta was working on were identical with the famed Amsdell Creek fauna, Ziegler queried why Gupta was working on New York material. To his amazement, Gupta insisted his collection was not from New York but was from the Himalaya, in fact from Nepal. Gupta offered ziegler co- authorship of a manuscript on this fauna, but ziegler declined (ziegler, pers. comm. 17 September 1990) It was not until the following year, in 1974, that Gupta came to Nepal and embarked on his series of Nepalese 'discoveries', seemingly well prepared.

We have thus no hesitation in rejecting this report and, with it, the contention that any of the sequence exposed on Phulchauki might extend into the Devonian.

\section{Chapagaon-Upper Nakhu Khola Pleistocene Vertebrates}

That Gupta's report (1975 c) of Pleistocene vertebrates from "Lukundol (adjoining Chapagaon at the head portion of Nakhu Khola)" is dubious has already been pointed out (Dongol, 1985, 1987; Talent et al., 1989). The reasons are as follows:

i. Years of searching by one of us (G.M.S.D.) and by numerous international scientists have failed to locate Pleistocene vertebrates anywhere within the Nakhu Khola watershed.

ii. The fauna is a typical Pinjor (early Pleistocene) fauna like ones from the vicinity of Chandigarh. That it includes a crocodile is curious as no crocodiles living or fossil, apart from Gupta's report, have ever been reported from the Kathmandu Valley.

iii. The valley of the Nakhu Khola has been excavated in lacustrine silts and muds, the Late Pleistocene Nakhu Khola Mudstone Radio-carbon dating of this unit (Kiyoshi Saijo, 
Journal of Nepal Geological Society, Vol. 7, 1991, 9-20

pers. comm., July 1990) admittedly some distance away, west of the Bagmati River at Kirtipur, gives an age of 24,640 $990 / 880$ Y BP. A stratigraphic equivalent in the north, referred to as the Gokarna Formation by Yoshida \& Igarashi (1984) has a similar age. If stratigraphic alignments across the Bagmati Valley are correct, the presence of an early Pleistocene fauna in the Nakhu Khola Mudstone near Chapagaon would be very strange indeed.

iv. There is no Lukundol (or Lukondul) near Chapagaon in the Nakhu Khola watershed. We suggest that Gupta's 'locality information' is gobbledygoox, the "Lukundol" part having come from gossip: oral information about one of Dongol's early Pleistocene localities in the kayseri-Nayankhandi Lignite, specifically his locality 3 , just below the village of Lukondul on the Khare Khola, a right bank tributary of the Bagmati River (Dongol, 1985, 1987).

In view of the above, we have no hesitation in categorizing this Gupta report as spurious and "Lukundol" adjoining Chapagaon as yet another of his phantom localities.

\section{Gidhniya Pleistocene Vertebrates}

The non-reproducibility of Gupta's (1984) report of another Pinjor (early Pleistocene) vertebrate fauna from Gidhniya in the Dang valley of western Nepal has already been pointed out (Jens Munthe in Talent et al., 1989, p. 580). Cainozoic vertebrates have indeed been found in the Dang Valley but no Pinjor fauna in the area specified by Gupta. We therefore conclude that the report is spurious and that, once again, hearsay has been involved in specification of the locality.

\section{Surkhet Foraminifers}

There can be no question regarding the provenance of the samples used by Tewari \& Gupta (1977) for their paper on Eocene foraminifers from the Surkhet Valley; they were supplied by Gopal S. Thapa of Department of Mines and Geology. We have elsewhere (Talent et al.,' 1989) referred to the bizarre episode concerning Thapa's elegant map obtained from him without a hint that publication was intended. Gupta and Tewari, in publishing Thapa's map (Tewari et al., 1977), provided a few inconsequential words of introduction, and for this gave themselves senior authorship. 


\section{Undocumented Identifications From Western Nepal.}

Gupta's anything-goes, inept taxonomy has been abundantly documented (eg. Talent et al., 1988, appendix, pp. 31-36). The unidentifiable has been confidently identified to species-level, and stratigraphic correlations asserted; it is not unusual to encounter Gupta identifications incorrect at family and, even phylum level. To accept Gupta identifications, without supporting illustrations, would therefore be the acme of recklessness. No credibility should therefore be accorded any of the Gupta identifications in works by others, e.g. "in publications by K.S. Valdiya et al. in the area adjacent to Nepal's western border. There is, of course, no question regarding Valdiya's competence as a field geologist, nor that of Gerhard Fuchs who has contributed so mightily to Himalayan geology, especially in Nepal. Unfortunately, some of Fuchs's Nepalese materials were made available to Gupta and publications without illustrations resulted (Gupta, 1971, 1976). Identifications in these works are best ignored.

\section{CONCLUDING REMARKS}

The pattern presented for Gupta's Nepalese reports is not out of keeping with the pattern developed over a 26-year period in his 456 or so publications. The disinformation edifice extends throughout his books and numerous review papers. These can be construed as being, in some measure, attempts to interrate his dubious and often manifestly spurious 'data' into the scientific database. Gupta's work has been demonstrated to be heavy with recycling of materials and plagiarised illustrations (Talent et al., 1989, 1990; Brock et al., 1990 in press). Many of his papers are shot through with large slabs of plagiarised text. Such plagiarised materials from impeccable sources may still retain value. It is nevertheless better to ignore all syntheses bearing Gupta's name and return to Gupta-free sources, to give value only to syntheses not drawing on Gupta materials or, better still, to go in quest of new data.

\section{REFERENCES}

Ahluwalia, A.D., Bhatia, S.B. , Bassi, U.K. \& Janvier, P., 1989. The peripatetic fossils: part 4 . Nature, $341,13-16$.

Anonymous, 1990. Scandal upon scandal. Nature, 343, 396. 
Journal of Nepal Geological Society, Vol. 7, 1991, 9-20

Bassi, U.K.,1989. The stratigraphy of the Kinnaur Tethyan Basin - a reappraisal. J. geol. Soc. India, 34,587 595.

Bhatia, S.B., et al., 1990. (Replies to V.J. Gupta). J. geol Soc. India, 35,655-664.

Bordet, P., Calvet, J., \& Pillet, J., 1960. La faune silurienne de Phulchauki pres de Kathmandu (Himalaya de Nepal). Bull. Soc. geol. France, ser.7,2,3-14.

Brock, G.A., Mawson, R., Talent, R.C., Encelbretsen, M. J., \& Talent, J.A., 1990. Spurious and Scrambled data: V.J. Gupta's contribution to the Prototethyan/Tethyan database. shallow Tethys 3 (Sendai, Japan), in press.

Dongol, G.M.S., 1985. Geology of the Kathmandu fluviatile lacustrine sediments in the light of new vertebrate fossil occurrences. Jour. Nepal geol. Soc. 3 (1\& 2), 43-57.

Dongol, G.M.S., 1987. The stratigraphic significance of vertebrate fossils from the Quaternary deposits of the Kathmandu Basin, Nepal. Newsl. stratigr., 18 (1),21-29.

Gupta, V.J., 1971. Contribution to the Lower Palaeozoic stratigraphy of western Nepal. Verh. Geol. B.-A. Wien, 1971 (3), 643-646.

Gupta, V.J., 1975 a. Upper Devonian conodonts from Phulchauki, Nepal. Himalayan Geology, 5, 156-168. Wadia Inst. Himalayan Geology, Delhi.

Gupta, V.J., 1975 b. Devonian conodonts from Himalaya. Chayanica Geologica, 1(1), 99-121.

Gupta, V.J., 1975 c. on the stratigraphic position of the Kathmandu Valley sediments, Nepal. Geogr. Helvetica 30 (1), $27-28$.

Gupta, V.J., 1976. Triassic conodonts from Nepal. Jour. geol. Soc. India, 17,562 .

Gupta, V.J., 1980. A note on the stratigraphic position of the Chandragiri Limestone, Nepal. Jour geol. Soc. India, 21, 141 . 
Gupta, V.J., 1984. Plio-Pleistocene mammals from Gidhniya Village, western Nepal. Geobios, 17 (4), 493-497.

Gupta, V.J., 1989. The peripatetic fossils: part 2. Nature, 341, $11-12$.

Gupta, V.J., 1990 a The peripatetic fossils: part 4 - a response to the co-authors. Nature, 343, 307-308.

Gupta, V.J., 1990 b. Discussion: comments by V.J. Gupta. Jour. geol. Soc. India, 35 (6), 649-655.

Gupta, V.J., \& Chhetri, 1977. Geology of the area around Phulchauki, Kathmandu, Nepal. Chayanica Geologica, 3(2), $133-146$.

Gupta, V.J., \& Termier, G., 1978. Lower Palaeozoic Echinodermata from Chandragiri pass, near Kathmandu, Nepal. Recent Researches in Geology, 7, 472-480. Hindustan Publishing Corporation, Delhi.

Gupta, V.J., \& Webster, G.D., 1976. Melocrinites from the Godavari Series of the Kathmandu Valley, Nepal. Jour. geol. Soc. India, 17, 413-414.

Lewin, R., 1989. The case of the "misplaced" fossils. Science, $244,277-279$.

Radhakrishna, B.P., 1989. Indian palaeontology under a cloud. Jour. geol. Soc. India, 34, 561-563.

Radhakrishna, B.P., 1990. Inaction on a Himalayan Scandal. Jour. geol. Soc. India, 35, 555 to 558.

Reed, F.R.C., 1912. Ordovician and Silurian fossils from the central Himalayas. Geol. Surv. India, Palaeontologia Indica, ser. 15,7 (2), 168 pp.

Sahni, A., 1989. Sahni Visit denied. Nature, 342, 338.

Stocklin, J., \& Bhattarai, K.D., 1977 (unpub). Geology of Kathmandu area and central Mahabharat Range. H.M.G.l U.N.D.P. Mineral Exploration Project Report, $86 \mathrm{pp}$. Kathmandu, Nepal.

Talent, J. A., 1989 a. The case of the peripatetic fossils. 
Journal of Nepal Geological Society, Vol. 7, 1991, 9-20

Nature, 338, 613-615.

Talent, J. A, 1989 b. The "misplaced" fossils. Science, 246, $740-741$.

Talent, J. A., 1989 c. Rhinos in Rio ? An update. The Australian Geologist, 73, 39-40.

Talent, J. A., 1990 a. The peripatetic fossils: part 5. Nature, $343,405-406$.

Talent, J.A., 1990 b. Himalayan geology again: Curiouser and spuriouser. The Australian Geologist, 74, 42-46.

Talent, J. A., 1990 c. Peripatetic fossils: V.J. Gupta's response rejected. Bull. Ind. Geol. Assoc., 23 (1), 39-61.

Talent, J. A., in press. Evaluation of V. J. Gupta's contributions to the Panjab University Research Bulletin. Res. Bull. Panjab univ.

Talent, J. A., Brock, G. A., Engelbretsen, M.J., Gaetani, M., Jell, P.A., Mawson, R., Talent, R.C. \& Webster, G.D.(1990). Himalayan Palaeontologic database polluted: plagiarism and other anomalies. Jour. geol. Soc. India, 35 (6), 569-585.

Talent, J.A., Brock, G. A., Engelbretsen, M.J., Kato, M., Morante, R. \& Talent, R. C., 1989. Himalayan palaeontologic database polluted by recycling and other anomalies. Jour. geol. Soc. India, 34, 575-586.

Talent, J. A., Goel, R. K., Jain, A. K., \& Pickett, J.W. (1988). Silurian and Devonian fossils of India, Nepal and Bhutan: biostratigraphic and palaeobiogeographic anomalies. Cour. Forsch.- Inst. Senckenberg, 106, 57 pp.

Tewari, B.S., \& Gupta, V.J., 1977. Foraminifera from the subathu Formation, Surkhet Valley, Western Nepal. Himalayan Geology 6 (for 1976), 209-219. Wadia Inst. Himalayan Geol., Dehra Dun.

Tewari, B.S. , \& Gupta, V.J., \& Thapa, G.S., 1977. Geology of the area around Surkhet Valley, western Nepal - a supplement. Bull. Indian geol. Assoc. 9 (2), $110-111$ (Imprint: December 1976). 
Waterhouse, J. B., 1989. Holy Himalayas - hoax or hogwash ? The Australian Geologist, 73, 41-42.

Waterhouse, J. B., 1990. The peripatetic fossils: Part 4-a. 